\title{
Who governs in (local) governance? Theoretical considerations and empirical evidence
}

\section{Mattia Casula}

Luiss University Rome / Department of Political Science

Rome - Italy

This article aims to discuss the possible actors that can determine public policies, and the influence of new decisional arenas on politics. This theoretical work presents the evolution of different models of producing public policies, to the transformations taking place with the adoption of the governance model. Using empirical evidence from the Italian case, the study of new decisional arenas for the determination of public policies shows that there are still several problems to be addressed. Such problems are connected, above all, with the uncertain democratic nature of these arenas, as well as with the impossibility to clearly attribute political responsibility to the choices adopted in these spaces. These are issues and future research questions to be resolved, limiting the analysis to specific case studies, preferably related to the local sphere.

Keywords: public policies; governance; participatory democracy; deliberative democracy; Italy.

\section{Quem governa na governança (local)? Reflexões teóricas e evidências empíricas}

O objetivo deste artigo - de natureza teórica — é discutir os possíveis atores que podem definir políticas públicas, bem como a influência que novas arenas decisórias exercem em relação à política. $\mathrm{O}$ artigo resgata a evolução de diferentes modelos de formulação de políticas públicas, até as transformações que vêm acontecendo com a adoção do modelo de governança. Por meio de evidências empíricas obtidas a partir do caso italiano, o estudo das novas arenas decisórias que influenciam na definição de políticas públicas mostra que existem diversos problemas relacionados, acima de tudo, a incerteza sobre a natureza democrática dessas arenas e a impossibilidade de claramente atribuir responsabilidade política pelas escolhas feitas. Essas são questões e futuras perguntas de pesquisa que devem ser respondidas e que limitam a análise a estudos de caso específicos, relacionados preferencialmente a esfera local. Palavras-chave: políticas públicas; governança; democracia participativa; democracia deliberativa; Itália.

\section{¿Quién gobierna en la gobernanza (local)? Reflexiones teóricas y evidencias empiricas}

El objetivo de este artículo — de naturaleza teórica - es discutir los posibles actores que pueden determinar políticas públicas, así como la influencia que nuevos espacios decisorios ejercen con relación a la política. El artículo rescata desde la evolución de diferentes modelos de producción de políticas públicas hasta las transformaciones que están teniendo lugar con la adopción del modelo de gobernanza. Por medio de evidencias empíricas obtenidas a partir del caso italiano, el estudio de los nuevos espacios decisorios que influencian en la determinación de políticas públicas muestra que existen diversos problemas relacionados, sobre todo, la incertidumbre sobre la naturaleza democrática de esos espacios y la imposibilidad de atribuir, claramente, responsabilidad política por las decisiones tomadas. Esas son cuestiones y futuras preguntas de investigación que deben responderse y que limitan el análisis a estudios de caso específicos, relacionados preferentemente a la esfera local.

Palabras clave: políticas públicas; gobernanza; democracia participativa; democracia deliberativa; Italia.

Article received on March 25, 2016 and accepted on February 1, 2017.

[Original version]

I would like to thank Arlo Poletti, the editors and the anonymous reviewers for their valuable advice and comments on previous versions of this article. 


\section{INTRODUCTION}

According to an interpretation widely accepted by political scientists, the study of public policies and their comprehension should not be limited to the mere reconstruction of the life cycle of the public policy. On the contrary, it should help to understand the more general structuring of the political system and the present form of government. This interpretation has its main reference in Theodore Lowi's analysis (1972) and in his well-known expression "policies determine politics".

Even though the academic community agrees nearly completely that it is crucial to understand politics together with the analysis of the policy-choices adopted, the excessive determinism of this conclusion has been called into question time and again by scholars who question the possible determinants of public policies and, retroactively, the role politics should have for their determination. For example, Castels (1982) identifies, starting from empirical observations, the political orientation of the party governments as the most important determinant for the adoption of different public policies. In this particular case, this interpretation was explained by the analysis of the determinants of the different welfare systems present in Western democracies. In fact, the author found that the most important reason for establishing welfare systems is the ideological orientation of the party in government. Left wing governments were notoriously more interventionist and more active in the fight against unemployment (even at the cost of increasing inflation), whereas conservative governments are less interventionist and more inclined to the logics of the market and deregulation.

Moreover, by discussing Lowis claim, several scholars (Ripley and Franklin, 1982; Windhoff-Héritier, 1987; Heinelt, 2007) argued that only specific public policies could really get to determine politics: the process of defining politics depends both on the nature of the actors involved and on the characteristics of the decisional arenas. In fact, policies that are committed to the market and deregulation are often incapable of determining politics. Public policies with a bottom-up nature, such as participatory budgeting and deliberative experiments, on the other hand, will have more chances to determine politics, given that the actors involved in the process share a common and long-term vision. In other words, sharing common objectives and the co-participation of a plurality of actors at the determination stage of public policies are, for Lowi, the key elements leading to a greater possibility of influencing politics.

All of these considerations are connected to the historic passage from government to governance (Rhodes, 1996). The traditional way of governing based on the central role played by the State, to a new involvement of different levels of governance (Multi-level Governance, as in Hooghe and Marks, 2001; Piattoni, 2010) and/or different types of actors (co-governance, as in Kooiman, 2003).

Even if applicable in different sectors of public administration, the study of new practices in governance is particularly suitable at local level. This is in part, due to the fact that,

a process of political and administrative decentralization is underway in many countries of the world and this process invariably places new responsibilities on local government. In addition, the direct interaction among citizens and government is most visible at the local level. [Wilson, 2000:52] 
Furthermore, some institutions of local government in both Europe and North America have an origin much older than their respective "national" states (Bobbio, 2002:13). This is the case for several American townships that were created before the formal ratification of the United States Constitution in 1778. It is also the case of several states that had forms of self-government before being incorporated into national states, for example, Catalonia in Spain, Scotland in the United Kingdom, and Baviera in Germany. This is the case in Italy where several municipalities predate the proclamation of the Kingdom of Italy, in 1861, which can be observed by the long line of mayors, chronicled in the archive of the City of Turin dating back to 1382. Moreover, these municipalities' ancient origins are still largely visible in the cultural traits and symbols that many Italian local governments continue to embrace in the form of rituals, emblems and names of places.

Taking into account the conceptual framework elaborated by Stein Rokkan (2002) in order to explain the evolution of the Western European political system, the Italian case has been used as the model "to explain the genetic, conditioned and decisive role (of the local communities), [...] in the formulation of the national states" (Baccetti, 2008:5). The Italian case has been influenced by the role historically played by the medieval comuni (basic administrative division in Italy).

According to Lippi (2011a, 2011b), the local level of governance became the privileged laboratory of the Italian administrative innovation in the last twenty years. More specifically, this bottom-up revolution has involved, from the beginning of 1990s, the organization and the implementation of administrative reforms with a corporate nature. Subsequently, it has experimented inclusive practices of governance in several sectors of policy, such as local and urban development and distribution of local public services. This began mainly due to the increasing use of participatory experiences from the Anglo-Saxon world involving new instruments, such as consensus conferences, deliberative survey, deliberative forum, etc. (Casula, 2015; Giannetti and Lewanski, 2007:15; Lewanski, 2013).

Starting from these considerations, through the review of literature on public policies and governance theories, this article will analyze possible actors and forms through which it is possible to determine policies, as well as influence the new decisional arenas on politics.

The article is structured in 5 sections including this introduction. Section 2 analyzes the different types of public policies in order to understand why policy makers pursue a specific cycle of action. The potential actors eligible in the process of policy determination are discussed in section 3 . Section 4 is the core of the article, bringing the concept of governance and the forms through which this concept can be used to understand models of shared and bottom-up determination of public policies, followed by section 5 with the conclusions. Particular attention will be dedicated to the Italian context, due both to its exceptional nature in comparison to other contexts and to the considerable body of research on this issue at the local level in Italy in the last decades.

\section{TYPES OF PUBLIC POLICIES}

A public policy can be defined as the set of measures that a policy maker decides to adopt in order to solve a problem that has a collective interest. Understood in this way, the study of a single public policy requires at least a double channel of analysis. On one hand, it is necessary to analyze the aim of the policy maker when they decide to pursue a specific cycle of action. In other words, it is necessary to 
study the nature of the public policy. On the other hand, it is necessary to analyze the characteristics of the actors involved in the process.

When it comes to the nature of public policy, it is important to clarify the main characteristics. Public policies present at least five characteristics (La Spina and Espa, 2011:18): 1) there are one or more recognized purposes and declared objectives that, among other things, contribute to allocate every single policy in a specific sector; 2 ) the availability of a set of resources and instruments in order to achieve these objectives; 3 ) there is a theory (most of the time) showing the validity of the resources and instruments able to help achieving the objectives; 4 ) they address a specific public interest; 5) the presence of a public authority that decides to be the policy's gatekeeper (invested with the power of coercion).

Coercion as a distinctive trait of public policy was first emphasized in the pioneering study of Lowi (1972). He pointed out the existence of four different types of public policies, each of them characterized by a different degree of coercion. Redistributive policies represent the maximum degree. In fact, as they imply the transfer of a great deal of resources from one social group to another, they necessarily require a central role played by public authorities. A certain degree of coercion is also present in regulative policies, which entail the imposition of specific norms with the aim of regulating the behaviors of actors on specific issues. A lower level of coercion is present in distributive policies in order to allocate economic resources to a group, above all with the use of taxation. Finally, an almost absent level of coercion can be found in constitutive policies, which involve constitutional changes, organization of public powers, and the institution of new administrative bodies. Among the criticisms that have been made regarding Lowi's classification, the most important are those towards the non-mutual exclusive of the four types (Aynley, 1988; Spitzer, 1987; Smith, 2002), and those on the problematic operationalization of the variables (Capano, 1993). In fact, it is possible that a policy shares characteristics of more than one of the types described above.

Considering the challenges faced by Lowi's analysis, Wilson (1980) considered two fundamental divisions: a) the degree of concentration/diffusion of the benefits; and b) the costs generated from the various measures taken. Based on this, the author makes the following distinction between the public policies: 1) public policies with concentrated costs and concentrated benefits, that present a high degree of conflict-potential; 2) public policies with concentrated costs and diffused benefits, characterized by the presence of a group that brings considerable costs, and of another group, notoriously more numerous, that will collect the benefits; 3) public policies with diffused costs and diffused benefits, that are scarcely used because they are poorly rewarding electorally; 4) public policies with diffused costs and concentrated benefits, that are more affordable for policy makers, since they are able to meet the needs of a specific group without penalizing others.

In response to what they saw as a shortcoming of Lowi's classification and Wilson's typology, several authors have argued for the need to consider another type of public policy, the so called "symbolic policy". As far as this policy is concerned, it is possible to consider the existence of at least two different types of symbolic policies. Gustafsson (1983:271), based on a previous study by Edelman (1964) defines symbolic policies as the "decisions which are not intended to be fully implemented". Gustafsson emphasized the existence of public policies that are difficult to implement, even if accurately formulated. He argued that this type of policy is created because of the growing process of 
decentralization within the public sector, which is connected to the growing use of multi-level logics in the attribution of both responsibility and power. For Pasquino (2009:248), symbolic policy is used to describe policies that are necessary in order "to strengthen and/or transform collective identities, sense of belonging, ties between those in positions of political power and the citizens, as well as to legitimatize those in power themselves". National and popular celebrations are two examples of this type of policy.

The above shows that there is a plurality of ways to study public policies. It is also true that a public policy, even if presenting specific characteristics in its initial stage, could be subject to variations leading to a reinterpretation of its initial nature. This means that there is a connection between the study of the types of public policies and the actors involved in their definition. The actors involved in defining public policies are discussed in the following section.

\section{COMPARING DIFFERENT ACTORS AND MODELS FOR THE DETERMINATION OF PUBLIC POLICIES}

Regarding the actors that are potentially involved in the determination of public policies, Jordan (1981) underlined the existence of four different decision making models. In each of them, the actors involved are different, both in number and in their qualities.

The party government model is the most well-known. It entrusts to the party and to its leaders a central role in the policy choices adopted at the national level. Nowadays, this model may barely be applicable in any national political systems. Its adoption will be desirable only with bipartite systems and in party systems with highly improved programming and great party discipline (Pasquino, 2009:234). Although it has been particularly suitable to the old mass parties, this model is not easily adapted to the changing structure of the latest models of parties, which have shown to be "catch-all" parties (Kircheimer, 1966).

The next model is Neo-corporatism. According to the definition given by Schmitter (1975), Neo-corporatism is a system of interest intermediation in which associations are limited, and the state gives these interest groups the monopoly of representation in exchange for influence over appointments to parliament. This model emerged in the late 1960s early 1970s as a substitute for the parliamentary processes in order to strengthen the executive branch, and it was elaborated in order to introduce emergency public policies (especially socio-economic emergency), legitimized by interest groups. This model needs to meet specific requirements to be established: 1) the presence of a pro-labor government; 2) the central organization of the groups; and 3) the monopoly of representation. Moreover, if the previous model showed production of public policies that were limited to the decisions made by the elite of a single party, in Neo-corporatism, despite an already limited degree of pluralism, it is possible to observe entrance for new actors that are constantly bargaining: namely the executive branch, trade unions and employers.

The last two models are the "iron triangles" and the "issue networks". In the first case, the metaphor of the triangle is connected to the solid nature of the actors involved in the process of definition

of public policies, i.e. congressional committees, independent federal agencies and interest groups that co-participate in the formulation of public policies, trying to protect their respective interests. The criticisms of this model - practically only ever used in the context of the U.S.A - concern its excessive rigidity, both in relation to the actors involved in the process and to its forms of working. 
For this reason, the model of the iron triangles was replaced by another one, less rigid. Heclo (1978) introduces the concept of issue networks, characterized by a wide and diverse number of actors (from public, private and third sector), making it difficult to distinguish between who is included and who is not included in the process.

However, more recently, the concept of "issue networks" has been compared to the concept of "policy communities", which shows a greater degree of closure and the presence of more stable relationships between the single actors involved in the process.

In order to understand the main differences between "issue networks" and "policy communities", it is possible to analyze them based on five different analytical dimensions: origins, objectives, actors involved, dominant values, and benefits. The comparison between these two models here uses a well-known article by Mark Thatcher (1998), "The Development of Policy Network Analyses: From Modest Origins to Overarching Frameworks".

Firstly, "the concept of 'policy community' was used and developed in studies of Britain from the 1970s onwards [...] the idea of another, very different type of network [i.e. the 'issue network'] was being established in the United States by Hugh Heclo" (Thatcher, 1998:391). Secondly, in a policy community, "policies were made and implemented between a myriad of interpenetrating organizations that formed policy communities", while "issue network consists of a large number of issue-skilled 'policy activists' drawn from conventional interest groups and sections of the government, together with academia and certain professions but also comprising expert individuals regardless of formal training" (Thatcher, 1998:391). Several differences are observed, in terms of the actors involved and their dominant values. For instance, while civil servants from government departments represent actors that are involved in policy communities that share the sense of community, issue networks are characterized by the presence of actors that change very frequently and the relationships between their members are infrequent and unstable. Consequently, these actors do not share a base of values since their constant change leads them to prefer material and imminent advantages more than common communitarian values. Finally,

in contrast to [...] other approaches, policy communities and issue networks present important benefits. 'Policy community' offered an enriching metaphor, capturing the coexistence of conflict and shared norms and framework, the closeness of policy-makers, the distinction between policy insiders and outsiders, and the difficulties encountered by new actors seeking to influence policy (cf. Heclo and Wildavsky, 1974). 'Issue network' incorporated the importance of both fragmentation and increasing specialization in policy formation. [Thatcher, 1998:392]

This section has shown different models for the determination of public policies identified in history. It was possible to observe that in each of them, the actors involved differ both numerically and qualitatively. This classification should be understood as a possibility to analyze a single socio-cultural context in which a specific public policy is formulated, as well as to analyze both the institutional characteristics of the different actors involved (or potentially involved) in the process, and the types of public policies. In other words, considering the chronological nature of these models, the decisional arenas are now more open, since a plurality of actors participates in the determination of public policies. Therefore, all of these considerations are connected with the necessity to observe 
changes in the actual decision-making process from hierarchically structured forms to new forms of coordination, reflected by new forms of governance.

\section{WHO OR WHAT DETERMINES POLICIES IN (LOCAL) GOVERNANCE?}

Developed as an alternative to Anglo-American managerialism (Kickert, 1997), theory of governance represented one of the most fundamental paradigms in the study of administrative policies from the 1990s. The use of the concept of governance has been so variegated in the last decades that a substantial ambiguity can be noted, as well as a loss of precision in its meaning. ${ }^{1}$ According to Kooiman (1999:70), ${ }^{2}$

The diversity of uses and the various definitions present a problem in understanding governance. [...] One may presume that different definitions and applications of governance are more appropriate and useful under different circumstances. Corporate governance therefore appears to be more relevant at the organizational level, while network, economic and governmentality approaches seem to be appropriate for sectorial governing situations, and governance as good governance, is more relevant to national situations and, as the word already indicates global approaches speak more to international or worldwide situations.

Considering this conceptual vagueness (Sartori, 1970), its different dissemination in all the areas of political science should not be surprising. For example, analyzing the potentialities and ambivalence of governance, Profeti (2010:16-23) underlined the use of the theory of governance in four specific sectors that synthesize the existing divisions in political science: i) the macro analysis of structures and political-institutional order in which it is possible to collocate the forms of public regulation; ii) administrative science; iii) international relations; and iv) analysis of public policies.

Political scientists adopting the theory of governance in the first sector presented by Profeti (2010) have interpreted the concept of governance as the means by which to study the changes taking place in the nature of the state (Gray, 1994; Rhodes, 1994). It is also the start of new rules for coordination of public action and regulation of contemporary society and the reconfiguration of the relationship between public and private and between state and market (Tricker, 1994). The science of administration has framed the concept of governance as a response to the dysfunctions of bureaucratic administration, proposing an alternative model to the New Public Management (NPM), as theorized by Hood (1991). Scholars of international relations and European studies used this concept to indicate the practices of coordination and the continuous search for multilateral agreements between states, sub-national levels of government and independent registered public/private actors on shared objectives. More specifically, within the study of international relations the concept of global governance is used to outline the new relationship between the burgeoning supranational organizations, nation-states and the new non-state actors (multinational corporations, NGOs, representatives of the private sector and

\footnotetext{
${ }^{1}$ As Cepiku (2005) pointed out, Van Kersbergen and Van Waarden (2004) calculated an exponential growth in Holland in the use of this term in journals specialized in public management ranging from 24 citations in 1990 to 603 in 2000.

${ }^{2}$ Based on previous work by Rhodes (1997), Kooiman (1999:68) proposed a list of ten "ways in which the term 'governance' is used in literature".
} 
civil society) that now share places in the decision-making process (Rosenau and Czempiel, 1992; Marchetti, 2016). Scholars of European integration (Hooghe and Marks, 2001; Bache, 2008; Piattoni, 2009), on the other hand, talk of multi-level governance to indicate the new forms of governance that are inclined to involve European, national and sub-national actors in several policy sectors. Finally, from the standpoint of public policy analysis, the concept of governance is studied in connection with the partnerships and interactions between (more or less institutional) public and private actors, and within different levels of government characterized by the absence of formal and hierarchical authorities and by the presence of horizontal interactions between the several actors involved in the policy process.

Based on the focus of this theoretical article, it is necessary to present the main international contributions on governance in political science and to discuss the ambiguous points in the field of governance practices currently in place.

More specifically, the analysis of the literature will focus on the classic contributions of the 1990s and the first half of the 2000s. The debate on governance is still very heated (Capano et al., 2012; 2015; Bevir and Rhodes, 2016), yet the choice of studying this issue reflects the need to discuss the essential contributions to the literature on governance and, the need to present a discussion about its uncertain democratic nature. First, the study introduces the literature on the concept of "governance as the minimal state where governance becomes a term for redefining the extent and form of public intervention" (Kooiman, 1999:68). Second, two contributions about new and old models of policy-making will be discussed.

Coining the aphorism "from government to governance", Rhodes $(1992,1996,1997,2000)$ highlighted the passage from forms of public services management based on the state dirigisme to a new fragmented form of delivering public services, which counts on the combination of actors from the public, private and third sectors.

This aphorism summarizes the shift from line bureaucracies to fragmented service delivery. After 1979, function-based policy networks based on central departments (or sections of them) changed in two ways. First, the membership of networks became broader, incorporating both the private and voluntary sectors. Second, the government swapped direct for indirect controls. British government privatized the utilities. It contracted-out services to the private sector. [...] It bypassed local authorities for special purpose bodies. It removed operational management from central departments and vested it in separate agencies. [Rhodes, 2000:348]

This passage has also been connected with the so-called 'hollowing out of the state', which has created both a progressive process of delegation of competencies to new powers, both supranational and local, and the creation of self-organized inter-institutional networks that contribute to the shared determination of public policies. Taking into account UK public sector reform in the 1980s and 1990s, Rhodes used this aphorism to understand four interconnected trends:

(1) Privatization and limiting the scope and forms of public intervention.

(2) The loss of functions by central and local government departments to alternative service delivery systems (such as agencies). 
(3) The loss of functions by British government to European Union institutions.

(4) Limiting the discretion of public servants through the new public management, with its emphasis on managerial accountability, and clearer political control through a sharper distinction between politics and administration. [Rhodes, 2000:363]

Both of Rhodes' aphorisms s, "from government to governance" and "hollowing out of the state", opened the way to an alight debate within the international academic community.

For example, Schick (2003), using the expression 'governing without (national) government', pointed out that, in the passage from government to governance, a slow weakening of the model of the state-nation took place. As a consequence, there were processes of decentralization and externalization of functions and activities to new institutional subjects, in order to create bureaucratic structures that are less formal and less hierarchical and to reduce the gap between state and citizens on the formulation and implementation of public policies. He wrote:

The nation-state played a critical role in the rise of political democracy and markets [...]. Nevertheless, the demand for performance is nibbling at the special status of the state [...]. These alternatives are encompassed in the word "governance" which has supplanted "government" in many discussions of political institutions and public policy. While some see governance merely as a broader term, others view it as a substitute for the nation-state. Governance connotes that tinkering with the machinery of government through civil service reform, budget practices and administrative re-organization [...] does not offer sufficient improvement in performance. [Schick, 2003:94-95]

Other scholars (Kettl, 2000, 2002; Mayntz, 2003; Reichard, 2001; Schedler, 2003) pointed out that the process of "hollowing out of the state" and the growing proliferation of cooperative relations between public and private actors is not necessarily opposite. In fact, the new network structures don't entirely replace traditional vertical relationships - both at the micro level of traditional bureaucracies and at the meso level between the different levels of the public administration. Rather, they tend to cohabit. In other words, this position on governance should be read in an evolutionary perspective of the structures and of the relationships traditionally found inside the public system. Therefore, it is like an incremental process in which different types of models of regulation are to be combined with each other.

Regarding the combination of new and old forms of governing, according to Kickert and Klijn (1997), governance can be defined as a third model of policy making which is alternative to the mono-centric or classic model and to the intergovernmental model. As it is well known, the mono-centric model described the advent and development of the welfare state, and it was characterized by a decisional centralization and hierarchical organization of management tasks. Since the sixties, this model has been facing several problems connected with the classic issues that characterize a hierarchical

\footnotetext{
${ }^{3}$ In order to explain the theory of governance, Rhodes (2000:346) elaborated seven aphorisms: i) "more control over less"; ii) "the weakness of the core executive"; iii) "the sour laws of unintended consequences"; iv) "the loss of trust"; v) "it's the mix that matters"; vi) "diplomacy and hands-off management"; vii) "from de-concentration to decentralization".
} 
functional model: its high rigidity, its poor horizontal communication of information, its segmentation, and its compartmentalization. For these reasons, a new model arose, i.e. the intergovernmental model. The central concepts of this model that rapidly permeated modern administrations - the notions of delegation and decentralization and a particular attention to the participatory nature of the policy maker - began to spread. It emphasized the presence of a bottom-up and polycentric system in which the inferior level of government participates in the definition of common policies. If this model was characterized by the presence of a plurality of actors that participate in the policy process, the third model was also marked by a strict interdependence of public and private actors that cooperated and participated together in the elaboration and implementation of public policies (stages of the policy cycle where the boundaries are increasingly unstable).

Considering the emerging challenges for modern public administration (i.e. internationalization, environmental protection, development of the new technologies, the culture of individuality), Kooiman $(1999,2003)$ underlined the presence of three typologies (interference, interrelation and intervention) that derived from the combined effect on the interaction between actors, structures and processes. The originality of Kooiman's work lies in his ability to link the old Weberian hierarchical governance with the prospective of self-governance, i.e., "the capacity of societal entities to provide the necessary means to develop and maintain their identity, by and large, by themselves - and thus show a relatively high degree of social-political autonomy" (Kooiman and van Vliet, 2000:360), in which the state limited itself to delegate to other actors the responsibility for the solution of specific problems (chart 1). In other words, it presents itself as open, flexible and directly connected with the process of decreasing public intervention such as in privatization and deregulation. For Kooiman, co-governance (or interrelation) as a form of interaction admits paternalistic forms of the public action when interacting, since the central authority participates on par with the social and economic subjects in the process. Therefore, they assume the forms of deliberative and negotiation processes where the single actors involved are constantly in interaction in order to come to a co-decision.

Combining these three modalities - hierarchical governance, co-governance, self-governance - with inclusivity, Profeti (2010:49-54) elaborated a typology of 12 possible types of arena (see Chart 1), by crossing four dimensions/arenas of inclusivity (universalistic, representative, selective and plethoric) with three roles played by public authority (interference, interrelation and intervention), and proposes a series of empirical references adopted in Italy. As for the arenas, they are: 1) the universalistic ones, that are similar to a pluralistic model of governance and are characterized by weak ties among the actors, dispersion of power, and an accentuated discussion in the case of decision, both when it comes to voting and to deliberation; 2) the representative arenas, that are new forms of negotiated programming in which the single actors are spokesmen of representative organizations of the public institutions and/or trade association and/or representative of common interests; 3 ) the selective arenas, that are closed and are characterized by the concentration of power in a restricted number of subjects, creating a clear and net distinction between those who take part at the table of consultation (and then for the determination of policies) and those who do not; 4) the plethoric arenas, that are characterized by the presence of a plurality of actors that, independently from their nature (public, private and mixed), are part of the same categories and/ or have common interests. 
The analysis of the combination for the most common modalities of governance and inclusivity of the actors in the determination of policies, particularly suitable to the local arena, must be carried out looking at the same time to its merits and its ambiguities. In fact, the perfect combination between practices of inclusion of the actors in policy formulation, voluntary participation and the launch of informal and collaborative relations between actors have been praised by several scholars. However, have also been criticized for their possibly problems of accountability.

\section{CHART 1 PREVALENT MODALITIES OF GOVERNANCE AND INCLUSIVITY}

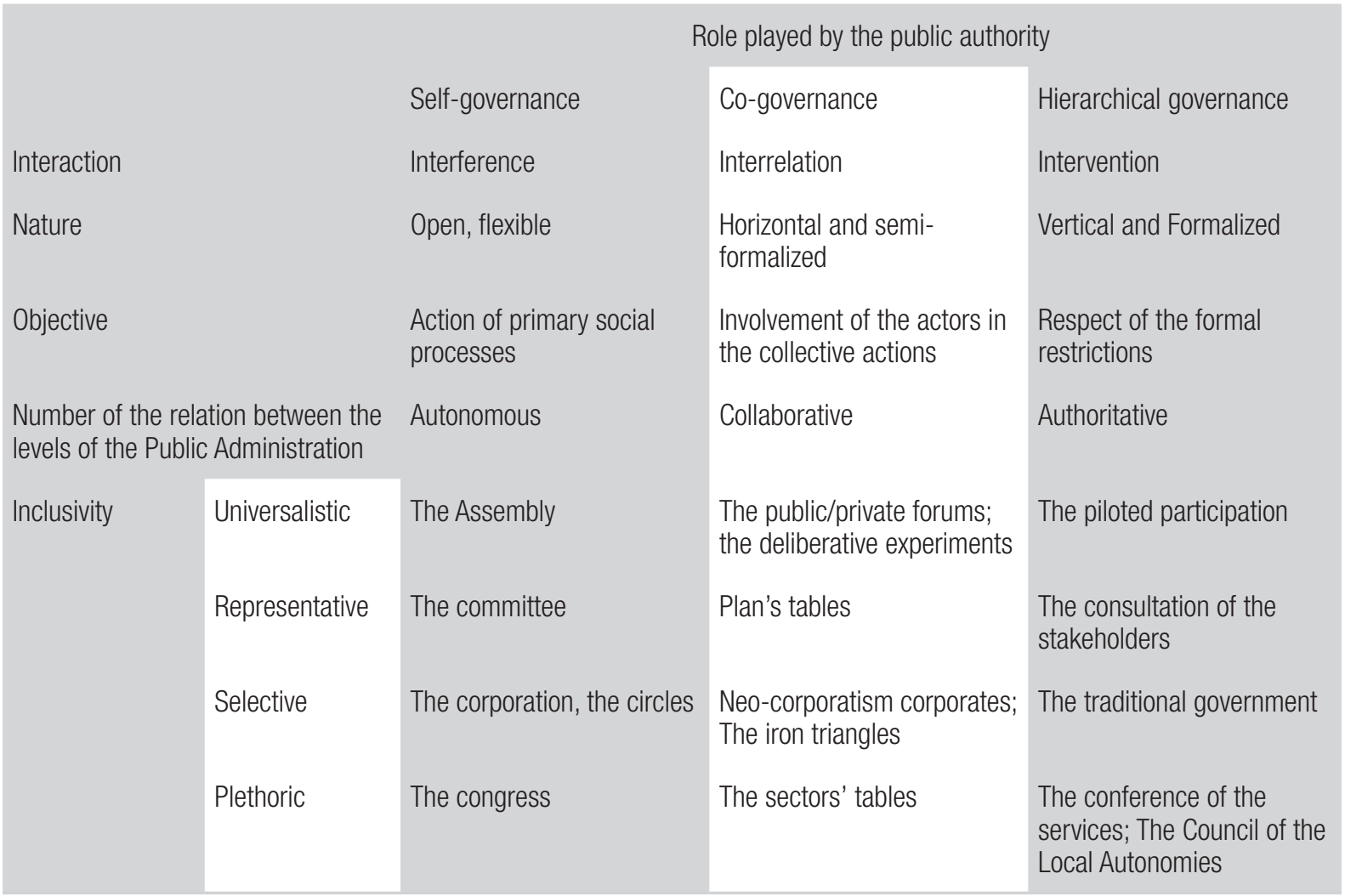

Source: Elaborated by the author based on Kooiman $(1999,2003)$ and Profeti (2010).

Stoker (1998) has identified some possible challenges and new dilemmas connected with the new practices of public management. In fact, he pointed out that the most important problems are related to the legitimacy of the new non-state actors involved in the new processes of governance and in the definition of public policies. In other words, if, on the one hand, opening to new internal and external actors previously excluded from the determination of policies expanded the participation to a plurality of actors, on the other hand it is more difficult to clearly distinguish the responsibilities of the institutional subjects involved in the resolution of problems with a common interest. For the voter, it is now increasingly difficult to have reliable parameters in order to verify the behavior of the rulers. At the same time, the reduced role of vigilance by elected assemblies in favor of an increase 
in the competencies of representative organizations in the negotiating moments is creating several problems for controlling the activities of the executive. Moreover, Stoker analyzed this problem in terms of conflict in the existing relationship between the principal and the agents due to the difficulty of measuring the performances of the agents and the possible situations of moral risk that can arise. In fact, according to the theory of agency (see Eisenhardt, 1989; Stiglitz, 1987), in situations where there is an increase in the margin of discretion for the possible behavior an agent can adopt, the zone of acceptability tends to flatten. This situation is perfectly suitable to the framework described given the impossibility to draw a clear distinction between policy makers and the study of power as a static element.

Recently, the critical and paradoxical effects of governance, and consequently its implication in the determination of the policies, have been located in the excessive tendency for inclusivity; and in the attempt to open the participation to subjects from the civil society and from the private sector in the decisional arenas. For example, Gloria Regonini (2005), considering the apparent inclusivity of these practices, analyzed this problem in terms of paradoxes of the philosophy of deliberative democracy:

The need to establish decision-making tables with a more inclusive participation than what you would get by relying only on the spontaneous evaluation of the individual is based on the observation that procedures that give back to individuals the choice of whether or not to bear the cost of participation tend to aggregate networks in which people with very intense and concentrated preferences (those who political science called high demanders or preference outliers) are systematically over-represented. On the other hand, the interests or points of view of the great mass of citizens are systematically under-represented. [Regonini, 2005:14, translated by the author]

The author recommends looking, with an empirical investigation into single case studies, at the effective participation of a large range of actors, observing both the absence of eventual division and disparities in the participation, as well as their real capacity to have an influence in the determination of the policies.

Regarding these issues, an accurate empirical investigation was recently conducted by Olmastroni (2013). The author investigated the perverse effects of the new sampling procedures adopted in order to guarantee the correct representativeness within the new practices of deliberative democracy. Taking into account the characteristics of the participants in two deliberative polls held in Turin and in Brussels between 2007 and 2009, the study showed that one of the most common techniques for ensuring the inclusiveness and representation of the participants during the deliberative processes (i.e. the drawing of the participants using a sampling process of socio-demographic variables), have several problems of self-selection. In order to make corrections in the selection process for those practices that "aspire to enable a sample of ordinary citizens" (Olmastroni, 2013:85), Olmastroni suggests considering additional individual characteristics. In fact,

in order to have a heterogeneous sample and increase the internal and external validity of the results obtained, it is necessary to monitor the interest and the political participation of citizens 
surveyed from the stage of recruitment and to structure the sample not solely on demographic criteria but also on socio-political characteristics of the studied population. [...] On these characteristics, as well as on the characteristics normally used in the sampling phase, it is possible to structure a sample of participants that reflects the actual distribution of the population. This is to avoid a sample composed of individuals that have specific skills or qualities leading them to adhere more easily to engage in the activities of political participation. [Olmastroni, 2013:85-86, translated by the author]

Thus, starting from the classic theories on governance and looking at the particularities concerning the new mechanisms of inclusiveness adopted within participatory and deliberative processes in order to guarantee the greater participation of different actors in the determination of public policies, this section suggested to circumscribe the analysis of who can determine politics at the local level. In this way, it is possible to conduct a more in-depth analysis of the arenas of power in which these processes are located. In fact, with respect to other levels of analysis, it allows a greater mapping of the actors involved in the definition of public policies and a greater knowledge of the social and economic fabric in which these dynamics arise.

\section{CONCLUSIONS}

This article has shown how the passage from the government to the governance paradigm is opening new perspectives of analysis for the study of the actors that can determine public policies. It has shown how the arenas in which the policy process is articulated are starting to be increasingly crowded and are determining the involvement of new actors previously excluded from the decision-making phase. They are actors of a heterogeneous nature and not necessarily related to a party as in the case of the party government model. Moreover, the boundaries between decision and implementation, as well as the line of demarcation between insiders and outsiders, are now increasingly unstable.

Nevertheless, there are many unsolved problems. First of all, the impossibility of clearly attributing responsibilities to the actors involved in the process of defining public policies represents a significant problem in terms of accountability. At the same time, the conflicts regarding power is creating several dilemmas on who gets what, when and how (Lasswell, 1936). Consequently, it is also creating problems for the coordination of the actors, for the establishment of self-regulated centers and to the extinction of a controlling center. Moreover, several questions on changing the rules to motivate the creation of these arenas continue to go unanswered. It could be a clear decision adopted by the center to interrupt the "circle voters-elected", or a choice intended to improve the circle's legitimacy. Finally, changing rules could be motivated by the desire to make citizens more responsible, considering that they are now both the decision makers and beneficiaries of public policies. Therefore, a careful empirical analysis on the new arenas is necessary and recommended, starting from the study of local governance and new forms of participatory and deliberative democracy, which are increasingly being adopted by sub-national levels of governance.

Finally, this article discussed the possible actors that can determine public policies, and the influence of new decisional arenas on politics. An in-depth analysis was conducted covering the inter- 
RAP | Who governs in (local) governance? Theoretical considerations and empirical evidence

national literature on governance, as well as on the paradoxical effects connected with the excessive tendency for inclusivity within the new practices of participatory and deliberative democracy. In addition, the article referred to the case of Italy, and offers theoretical references about other countries in which these practices are implemented gradually with more frequency. This is the case of Brazil that hosted, in 1989, the first participatory budgeting experience in the city of Porto Alegre (Wampler, 2012) and has presented an increasing number of these practices in different sectors (Coelho, 2014; Coelho and Nobre, 2004), experiences favored by the current policies of sub-national decentralization (Vlahos, 2013; Grin, 2016). 


\section{REFERENCES}

BACCETTI, Carlo. La nuova politica locale. Turin: Utet Università, 2008.

BACHE, Ian. Europeanization and multilevel governance cohesion policy in the European Union and Britain. Lanham: Rowman \& Littlefield, 2008.

BEVIR, Mark; RHODES, Roderick A. W. Rethinking governance: ruling, rationalities and resistance. New York: Routledge, 2016.

BOBBIO, Luigi. I governi locali nelle democrazie contemporanee. Roma-Bari: Laterza, 2002.

CAPANO, Giliberto. Le tipologie delle politiche pubbliche: una strada senza uscita. Rivista Italiana di Scienza Politica, v. 3, n. 3, p. 549-588, 1993.

CAPANO, Gilberto; HOWLETT, Michael; RAMESH, M. (Ed.). Varieties of governance: dynamics, strategies, capacities. London: Palgrave Macmillan, 2015.

CAPANO, Gilberto; RAYNER, Jeremy; ZITO, Anthony R. Governance from the bottom up: complexity and divergence in comparative perspective. Public Administration, v. 90, n. 1, p. 56-73, 2012.

CASTELS, Francis. The impact of parties: politics and policies in democratic capitalist states. London; Beverly Hills: Sage, 1982.

CASULA, Matia. Opportunity structures for citizens' participation in Italian regions: a case study. Journal of Public Deliberation, v. 11, n. 2, 2015.

CEPIKU, Denita. Governance: riferimento concettuale $\mathrm{o}$ ambiguità terminologica nei processi di innovazione della PA? Azienda Pubblica, v. 1, p. 105-131, 2005.

COELHO, Vera Schattan Pereira. A brief reflection on the Brazilian participatory experience. Journal of Public Deliberation, v. 10, n. 1, 2014.

COELHO, Vera Schattan Pereira; NOBRE, Marcos. Participação e deliberação. Teoria democrática e experiências institucionais no Brasil contemporâneo. São Paulo: Editora 34, 2004.

EDELMAN, Murray. The symbolic uses of politics. Urbana: University of Illinois Press, 1964.

EISENHARDT, Kathleen M. Agency theory: an assessment and review. The Academy of Management Review, v. 14, n. 1, p. 57-74, 1989.
GIANNETTI, Daniela; LEWANSKI, Rodolfo. Inclusione, efficacia e qualità della deliberazione: uno studio di caso. Rivista Italiana di Politiche Pubbliche, n. 2, p. 15-48, 2007.

GRAY, John. Limited government. In: MCKEVITT, David; LAWTON Alan (Ed.). Public sector management: theory, critique \& practice. London: Sage, 1994.

GRIN, Eduardo. Decentralization in San Pablo city: construction and deconstruction of Subprefectures and the limits to implement local power. In: WORLD CONGRESS OF POLITICAL SCIENCE, $24^{\text {th }}, 2016$, Poznań.

GUSTAFSSON, Gunnel. Symbolic and pseudo policies as responses to diffusion of power. Policy Sciences, v. 15, n. 3, p. 269-287, 1983.

HECLO, Hugh. Issue networks and the executive establishment. In: KING, Anthony (Ed.). The new American political system. Washington, DC: American Enterprise Institute, 1978. p. 87-124.

HECLO, Hugh; WILDAVSKY, Aaron. The private government of public money. London: Macmillan, 1974.

HEINELT, Hubert. Do policies determine politics? In: FISCHER, Frank; MILLER, Gerald J.; SIDNEY, Mara. Sidney. Handbook of public policy analysis: theory, politics, and methods. Boca Raton; Londres; New York: CRC Press, 2007. p. 109-119.

HOOD, Christopher. A public management for all seasons? Public Administration, v. 69, n. 1, p. 3-19, 1991.

HOOGHE, Liesbet; MARKS, Gary. Multi-level governance and European integration. Lanham: Rowman \& Littlefield Publishers, 2001.

JORDAN, Grant. Iron triangles, woolly corporatism, or elastic nets: images of the policy process. Journal of Public Policy, v.1, n. 1, p. 95-123, 1981.

KELLOW, Aynsley. Promoting elegance in policy theory: simplifying Lowi's arenas of power. Policy Studies Journal, v. 16, n. 4, p. 713-724, 1988.

KETTL, Donald F. The transformation of governance: globalization, devolution, and the role of government. Public Administration Review, v. 60, n. 6, p. 488-497, 2000.

KETTL, Donald F. The transformation of governance: public administration for the twenty-first century. Baltimore: Johns Hopkins University Press, 2002. 
KICKERT, Walter J. M. Public governance in the Netherlands: an alternative to Anglo-American "manageralism". Public Administration, v. 75, n. 4, p. 731-752, 1997.

KICKERT, Walter J. M.; KLIJN, Erik-Hans; KOPPENJAN, Joop (Ed.). Managing complex networks: strategies for the public sector. London: Sage, 1997.

KIRCHHEIMER, Otto. The transformation of the Western European party systems. In: WEINER, Myron; LaPALOMBARA, Joseph; BINDER, Leonard. Political parties and political development. Princeton: Princeton University Press, 1966.

KOOIMAN, Jan. Governing as governance. London: Sage Publications, 2003.

KOOIMAN, Jan. Social-political governance: overview, reflections and design. Public Management Review, v. 1, p. 87-92, 1999.

KOOIMAN, Jan; VLIET, Martijn van. Self-governance as a mode of societal governance. Public Management: An International Journal of Research and Theory, v. 2, n. 3, p. 359-378, 2000.

LA SPINA, Antonio; ESPA, Efisio. Analisi e valutazione delle politiche pubbliche. Bologna: Il Mulino, 2011.

LASSWELL, Harold. Politics: who gets what, when, how. Nova York: McGraw-Hill, 1936.

LEWANSKI, Rodolfo. Institutionalizing deliberative democracy: the 'Tuscany laboratory'. Journal of Public Deliberation, v. 9, n. 1, 2013.

LIPPI, Andrea. Evaluating the 'quasi federalist' programme of decentralisation in Italy since the 1990s: a side-effect approach. Local Government Studies, v. 37, n. 5, p. 495-516, 2011 a.

LIPPI, Andrea. Gli enti locali. In: CAPANO, Giliberto; GUALMINI, Elisabetta. Le pubbliche amministrazioni in Italia. Bologna: Il Mulino, 2011b. p. 179-209.

LOWI, Theodore. Four systems of policy, politics and choice. Public Administration Review, v. 32, n. 4, p. 298-310, 1972.

MAYNTZ, Renate. From government to governance: political steering in modern societies. In: SUMMER ACADEMY ON IPP, Sept. 2003, Wuerzburg.

MARCHETTI, Raffaele. Global strategic engagement: states and non-state actors in global governance. London: Lexington Books, 2016.
OLMASTRONI, Francesco. Partecipanti e non partecipanti. Limiti di rappresentatività in pratiche di democrazia deliberativa, Rivista Italiana di Scienza Politica, v. 1, p. 57-96, 2013.

PASQUINO, Gianfranco. Nuovo corso di scienza politica. Bologna: Il Mulino, 2009.

PIATTONI, Simona. Multi-level governance: a historical and conceptual analysis. Journal of European Integration, v. 31, n. 2, p. 163-180, 2009.

PIATTONI, Simona. The theory of multi-level governance: conceptual, empirical, and normative challenges. Oxford: Oxford University Press, 2010.

PROFETI, Stefania. Il potere locale tra politica e politiche. Il mosaico della governance nell'area vasta fiorentina . Soveria Mannelli: Rubbettino Editore, 2010.

REGONINI, Gloria. I paradossi della democrazia deliberativa. Stato e Mercato, v. 1, p. 3-31, 2005.

REICHARD, Christoph. New approaches to public management. In: KÖNIG, Klaus, SIEDENTOPF, Heinrich (Ed.). Public administration in Germany. Baden-Baden: Nomos, 2001.

RHODES, Roderick A. W. Beyond Whitehall: researching local governance. Social Sciences, v. 2, n. 13, 1992.

RHODES, Roderick A. W. The governance narrative. Key findings and lessons from the ESRC's Whitehall Programme. Public Administration, v. 78, n. 2, p. 345- 363, 2000.

RHODES, Roderick A. W. The hollowing out of the state. Political Quarterly, v. 65, p. 138-151, 1994.

RHODES, Roderick A. W. The new governance: governing without government. Political Studies, v. 44, n. 4, p. 652-667, 1996.

RHODES, Roderick A. W. Understanding governance: policy networks governance, reflexivity and accountability. Buckingham: Open University Press, 1997.

RIPLEY, Randall B.; FRANKLIN, Grace A. Bureaucracy and policy implementation. California: Dorsey Press, 1982.

ROKKAN, Stein. Stato, nazione e democrazia in Europa. Bologna: Il Mulino, 2002.

ROSENAU, James N.; CZEMPIEL, Ernst-Otto (Ed.). Governance without government: order and change 
in international relations. Cambridge: Cambridge University Press, 1992.

SARTORI, Giovanni. Concept misformation in comparative politics. The American Political Science Review, v. 64, n. 4, p. 1033-1053, 1970.

SCHEDLER, Kuno. Public governance: politische steuerung un public management 2003. St. Gallen: Universität St. Gallen, 2003.

SCHICK, Allen. The performing State: reflection on an idea whose time has come but whose implementation has not. OECD Journal on Budgeting, v. 3 , n. 2, p. 71-103, 2003

SCHMITTER, Philippe. Corporatism and public policy in authoritarian Portugal. London: Sage $\mathrm{Pu}-$ blications, 1975.

SMITH, Kevin. Typologies, taxonomies, and the benefits of policy classification. Policy Studies Journal, v. 30, p. 379-395, 2002.

SPITZER, Robert. Promoting policy theory: revising the arenas of power. Policy Studies Journal, v. 15, p. 675- 689, 1987.

STIGLITZ, Joseph E. Principal and agent. The new Palgrave: a dictionary of economics. United Kingdom: Palgrave Macmillan, 1987. v. 3, p. 966-971.

STOKER, Gerry. Governance as theory: five propositions. International Social Science Journal, v. 50, n. 1, p. 17-28, 1998

THATCHER, Mark. The development of policy network analyses: from modest origins to overarching frameworks. Journal of Theoretical Politics, v. 10, n.4, p. 389-416, 1998.

TRICKER, Robert I. International corporate governance, text readings and cases. New York: Prentice Hall, 1994.

VAN KERBERGEN, Kees; VAN WAARDEN, Frans. Governance as a bridge between disciplines: crossdisciplinary inspiration regarding shifts in governance and problems of governability, accountability and legitimacy. European Journal of Political Research, v. 43, p. 143-171, 2004.

VLAHOS, Nick. The politics of subnational decentralization in France, Brazil, and Italy. Journal of Public Deliberation, v. 9, n. 2, p. 1-29, 2013.

WAMPLER, Brian. Participatory budgeting: core principles and key impacts. Journal of Public Deliberation, v. 8, n. 2, p. 1-13, 2012.

WEINER, Myron; LaPALOMBARA, Joseph; BINDER, Leonard. Political parties and political development. Princeton: Princeton University Press, 1966.

WILSON, James Q. The politics of regulation. New York: Basic Books, 1980.

WILSON, Robert H. Understanding local governance: an international perspective. Revista de Administração de Empresas, v. 40, n. 2, p. 51-63, 2000.

WINDHOFF-HÉRITIER, Adrienne. Policy-analyse. Eine Einführung. Frankfurt; New York: Campus, 1987.

\section{Mattia Casula}

$\mathrm{PhD}$ Student, and currently Adjunct Professor in Analysis and Evaluation of Public Policies and International Public Policies at the Department of Political Science, Luiss University Rome. E-mail: mattia.casula@hotmail.it. 